\title{
The potential role of HIV-specific CD38-/HLA-DR+ CD8+ T cells in viral suppressive activity and cytotoxicity in HIV controllers
}

\author{
Stéphane Hua*, Camille Lecuroux, Asier Saez-Cirion, Gianfranco Pancino, Isabelle Girault, Martine Sinet, \\ Olivier Lambotte, Alain Venet
}

From Abstracts from International Symposium HIV and Emerging Infectious Diseases 2014

Marseille, France. 21-23 May 2013

\section{Introduction}

In HIV-1 infection, some rare patients called HIV controllers (HICs) are capable to spontaneously control viral replication in vivo. Interestingly, HICs exhibit higher frequency of a particular activated phenotype CD38-HLADR+ HIV-specific CD8+ T cells. The aim of this study was to characterize this profile and evaluate its role in HICs.

\section{Materials and methods}

To investigate the functionality of the CD38-HLA-DR+ profile, we compared it with the classically activated phenotype CD38+HLA-DR+ by evaluating several qualitative parameters: (1) activation measured by CD69, CD25, CD71, CD40 and Ki67 expression, (2) memory parameters measured by proliferation capacity, CD127 and Bcl-2 expression, cytokine production measured by IL-2 production and (3) cytotoxic activity. We also determined the mechanism responsible for this particular profile.

\section{Results}

CD38-HLA-DR + cells exhibited a more resting profile than CD38+HLA-DR+ cells marked by a lower expression of several activation markers. Although they presented similar ex vivo profile especially concerning survival, IL-2 production, CD38-HLA-DR + cells displayed significantly higher HIV-specific cytotoxic capacity after in vitro culture compared to CD38+HLA-DR+ cells (13\% [7\%-23\%] vs. $7 \%$ [3\%-11\%], $\mathrm{p}=0.02)$. Furthermore only the frequency of CD38-HLA-DR + HIV-specific CD8+ T cells correlated with the capacity of $\mathrm{CD} 8+\mathrm{T}$ cells to inhibit viral replication ex vivo $(\mathrm{r}=0.32, \mathrm{p}<0.0001)$. Moreover, the CD38-HLA-DR+

INSERM U1012, Le Kremlin Bicêtre, France profile was preferentially displayed after activation by low doses of antigen. These results are in line with the enhanced expression of this profile in patients which exhibit high functional sensitivity $(\mathrm{r}=0.41, \mathrm{p}=0.01)$.

\section{Conclusions}

Collectively, these data highlight the cytotoxic role of CD38-HLA-DR+ expressing HIV-specific CD8+ T cells in HICs and we provide insights into the mechanism of its induction. Induction of this type of protective cell subset could be an important goal in vaccine strategies.

Published: 23 May 2014

doi:10.1186/1471-2334-14-S2-P64

Cite this article as: Hua et al.: The potential role of HIV-specific CD38-/

HLA-DR+ CD8+ T cells in viral suppressive activity and cytotoxicity in HIV controllers. BMC Infectious Diseases 2014 14(Suppl 2):P64.

Submit your next manuscript to BioMed Central and take full advantage of:

- Convenient online submission

- Thorough peer review

- No space constraints or color figure charges

- Immediate publication on acceptance

- Inclusion in PubMed, CAS, Scopus and Google Scholar

- Research which is freely available for redistribution 